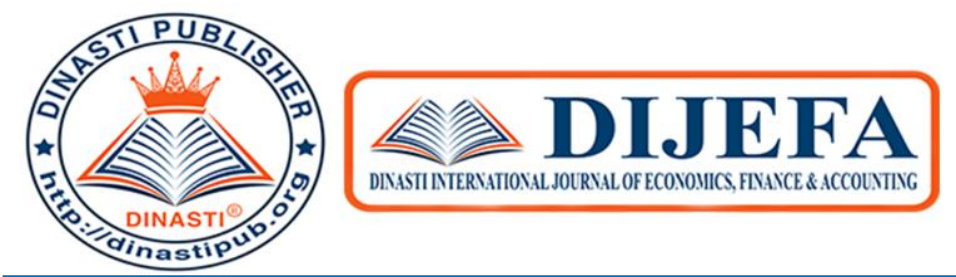

+6281387654578 ()

+6281387654578 (Q)

https://dinastipub.org/DIJEFA (2)

dinasti-info@gmail.com (๑)

\title{
EFFECT OF LEADER MEMBER EXCHANGE, ORGANIZATIONAL CULTURE AND EMPLOYEE ENGAGEMENT ON ORGANIZATIONAL CITIZENSHIP BEHAVIOR (CASE STUDY GEN Y IN PERUM LPPNPI)
}

\author{
Budi Mahmudi ${ }^{1)}$, Farida Elmi ${ }^{2}$ \\ ${ }^{1,2)}$ Master of Management, Mercu Buana University, Jakarta, Indonesia
}

ARTICLE INFORMATION

Received: $15^{\text {th }}$ March 2020

Revised: $23^{\text {th }}$ March 2020

Issued: $25^{\text {th }}$ April 2020

Corresponding author:

Budi Mahmudi

E-mail:

bmahmudi.airnav@gmail.com

farida.elmi@mercubuana.ac.id

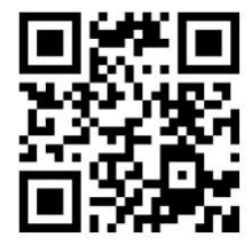

DOI:10.31933/DIJEFA
Abstract: This study aims to determine the effect of the leader member exchange, organizational culture, employee engagement on organizational citizenship behavior. This type of research is descriptive verification method. The population of all employees of Perum LPPNPI, decision-probability sampling technique with a sample of 200 employees. Data Analysis Structural Equation Modeling (SEM) method Partial Least Square (PLS) with 6.0 WarpPLS program. The results showed that the leader member exchange have a significant effect on employee engagement, organizational culture have a significant effect on employee engagement, employee engagement significantly influence the organizational citizenship behavior, leader member exchange have a significant effect on organizational citizenship behavior, and organizational culture significant effect on organizational citizenship behavior.

Keywords: Leaders Member Exchange, Organizational Culture, Employee Engagement, Organizational Citizenship Behavior, WarpPLS.

\section{INTRODUCTION}

Human resources are tied (disengagement) is needed by the company, because this attitude is the mental attitude of employees devoted to the existence of the company. When the decreased employee engagement, will give a very big loss for the company. Employees who are not bound tend to show lackluster attitude in the works, it will affect the company's performance.

Organizational Citizenship Behavior (OCB) to the employees of Perum LPPNPI still said to be not good enough. This is evidenced by the small number of employees who are willing to provide assistance to co-workers who are having difficulty, some employees are not willing to work more than an hour a contract of employment without extra pay, and there are some employees who are not abiding by the company's rules, for example take a break in 
excess of time specified, using the working hours for personal interests outside the office, and others.

Generation millennial and post-millennial has a character or identity that is quite unique. The generation is labeled with the generation of tech-savvy, social, expressive and connected. According to Ali and Purwandi (2017: 25), the main characteristic of this generation is connected, creative and confidence. The generation has a character that is connected between one person to another through the Internet or social media. While the generation of creativity which are out of the old habits (out of the box), and tend to be innovative. According to Suryadi (2014: 4) that the strong character of Gen Y tends to be negative is individualistic and not loyal or can be referred to as fleas in the working world. Individualistic nature of Gen $\mathrm{Y}$ is one result of the ease of communications technology so that the quality of interpersonal communication is often overlooked.

Indonesian Air Navigation Services Provider (Perum LPPNPI) to implement the provision of air navigation services in accordance with the applicable standards in order to achieve efficiency and effectiveness in the flights of national and international scope.

Employees who are still breaking the rules on such as when to come to work not on time, lazing when work usually happens in the millenial generation employees. Lack of career development initiatives in the generation $\mathrm{X}$ also indicated that only the millenial generation who enrolled to increase knowledge and know-how in bidanngnya, these things come into conscientiouness aspects and civic virtu.

Employees sometimes to refuse overtime due to work overload, it demonstrates a lack of altruism aspect. Still do not know the employee is found between other divisions and some times there is a conflict between members of the team or the other team because every team competing in increasing production so that inter-team do not support each other, which refers to aspects courtesy. Based on the results of pre-survey concluded that organizational citizenship behavior of employees of Perum LPPNPI are less, which is shown from the aspect of sportsmanship, conscientiousness, civic virtue, courtesy and altruism. In the pre-survey results are also visible differences between generation $\mathrm{X}$ and generation millenial shown in conscientiouness aspects and civic virtue.

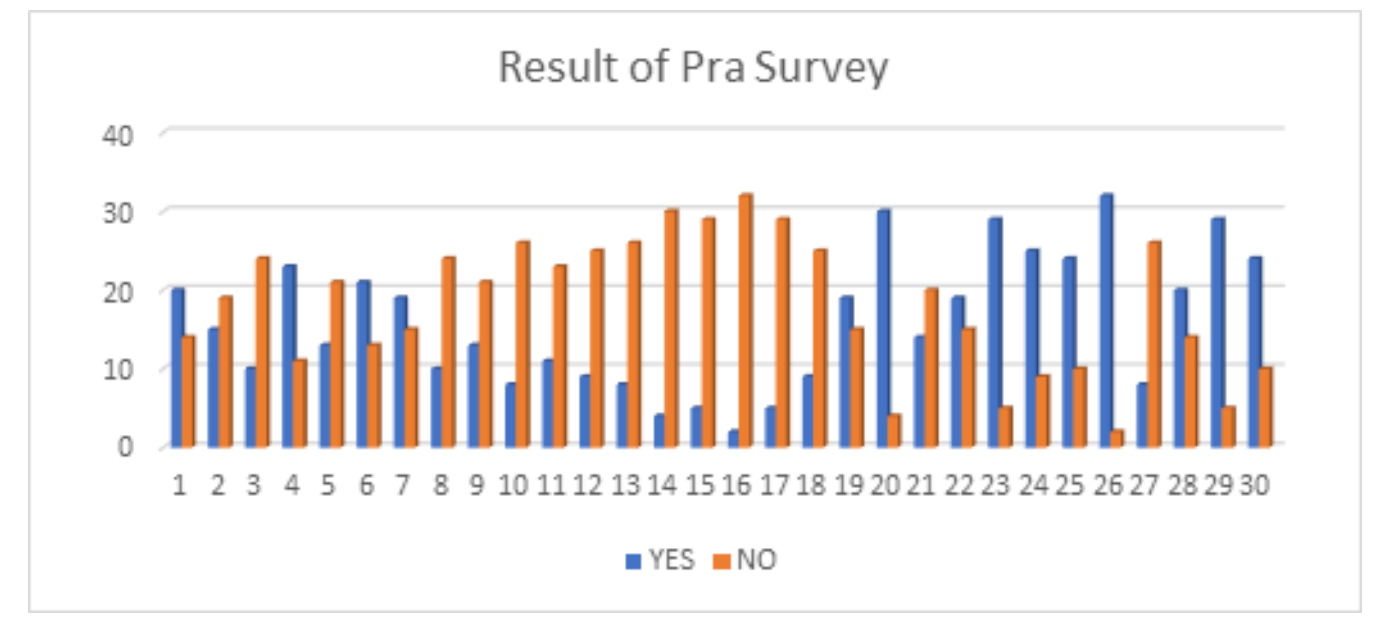




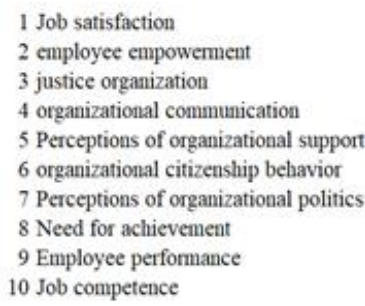

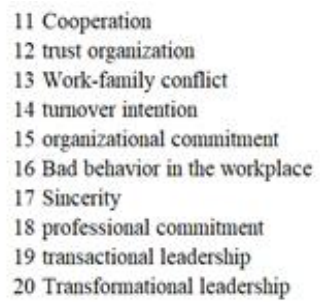

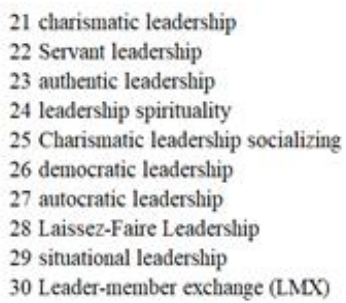

Source: Authors (2020)

\section{Picture 1. Results of Pra Survey of Leader Member Exchange, Organizational Culture, Employee Engagement and Organizational Citizenship Behavior of Perum LPPNPI Employees}

Based on observations made by the researchers showed that the Organizational Citizenship Behavior (OCB) to the employees of Perum LPPNPI still said to be not good enough. It is evidenced by the small number of employees who are willing to provide assistance to co-workers who are having difficulty, some employees are not willing to work more than an hour a contract of employment without extra pay, and there are some employees who are not abiding by the company's rules, for example taking an hour break in excess of time specified, using the working hours for personal interests outside the office, and others. Based on these phenomena can be indicated that the Organizational Citizenship Behavior (OCB) to the employees of Perum LPPNPI still relatively low.

This is also supported by the results of research conducted by Humairoh (2017) states that organizational culture positive and significant impact on employee engagement with the value of the $t(12.724)>t$ table $(1.960)$ and a significant value $(0.000)<0.05$. This means that the organizational culture is definitely needed by an employee to be able to achieve a high employee engagement, employee engagement although by its nature it is very relative magnitude or different from the others.

The results of another study conducted by Abas (2017) The Effect of Organizational Culture and Leadership Style towards Employee Engagement and Their Impact towards Employee Loyalty, stating that organizational culture positive and significant impact on employee engagement with the $t$ value (5.640)> $t$ table (1.960) and a significant value $(0.000)$ $<0.05$.

Based on the background of the problems described above, the subject matter in this study were 1) whether the leader member exchange effect on employee engagement ?, 2) whether the organizational culture influence on employee engagement? 3) whether the leader member exchange effect on organizational citizenship behavior? 4) whether the organizational culture influence on organizational culture citizenship behavior?, 5) whether the employee engagement affects the organizational citizenship behavior?, 6) whether leader member exchange take effect on organizational citizenship behavior through employee engagement as a mediating variable ?, and 7) whether the organizational culture take effect on organizational citizenship behavior through employee engagement as mediating variables? From the formulation of the problem, then the purpose of this study were 1) to determine the effect of the leader member exchange on employee engagement, 2) to determine the influence of organizational culture on employee engagement, 3 ) to determine the effect of exchange members of the organizational leader citizenship behavior, 4) to determine the influence of organizational culture on organizational citizenship behavior, 5) to determine the effect of 
employee engagement to organizational citizenship behavior, 6) to determine the effect of the leader member exchange on organizational citizenship behavior through employee engagement as a mediating variable, and 7) to determine the effect of organizational culture on organizational citizenship behavior through employee engagement as a mediating variable.

\section{LITERATURE REVIEW}

Leaders Member Exchange

Leader Member Exchange (LMX) is one of the unique leadership approach with a focus on the special relationship created by the leaders of each of his subordinates (Northouse, 2013: 87). According Rival (2014: 155-157), the dimensions of leader member exchange, namely: 1) Affect (affection), referring to the familiarity between one individual to individual. This familiarity alone does not regard social stasus. Interactions can be formed by employee relations and leadership, led by leaders and employees with employees. Aspects of affection can be the most dominant element and whether or not can depend on the type of relationships that exist in the workplace. 2) Contribution (contribution), perception of activities oriented to a certain level tasks between leaders and employees to achieve common goals. The level of contribution of a person can be seen from how much work and information obtained. 3) Loyalty (loyalty), how leaders and employees mutually supportive action and characters to each other in all situations. Loyalty one company's employees and leaders are needed for the sustainability leader member exchange that will have an impact on company performance. 4) Professional respect refers to respect or awe at the work being done to others. Employees who put a high respect to the performance and interaction of leaders are expected to apply the good values in their everyday work. how leaders and employees mutually supportive action and characters to each other in all situations. Loyalty one company's employees and leaders are needed for the sustainability leader member exchange that will have an impact on company performance. 4) Professional respect refers to respect or awe at the work being done to others. Employees who put a high respect to the performance and interaction of leaders are expected to apply the good values in their everyday work. how leaders and employees mutually supportive action and characters to each other in all situations. Loyalty one company's employees and leaders are needed for the sustainability leader member exchange that will have an impact on company performance. 4) Professional respect refers to respect or awe at the work being done to others. Employees who put a high respect to the performance and interaction of leaders are expected to apply the good values in their everyday work.

According Suhermin (2012) in Kartika (2016: 36) Leader Member Exchange (LMX) is a high quality control over the leaders of subordinate the desired results. These results include things like giving assignments interesting and fun, delegation of responsibility and authority of the larger, more sharing of information, participation in making most of the decisions a leader, a real appreciation (such as salary increases, special allowances, support and personal approval, and ease of career subordinates (eg recommending promotions, provide development assignments that have a high visibility). 
Organizational culture

According Wibowo (2013: 37), organizational culture is a common value system within an organization that determines the degree of how employees carry out activities to achieve organizational goals. According to Edison (2016: 131), the dimensions of organizational culture, namely: 1) Self-awareness, members of the organization with awareness work to get satisfaction from their work, develop themselves, and obey the rules. 2) aggressiveness, union members set goals that are challenging but realistic. Members of the organization set a work plan and a strategy to achieve that goal and pursue it with enthusiasm. 3) Personality, members of the organization to be respectful, friendly, open, and sensitive to the satisfaction of the group. 4) Performance, members of the organization have a value of creativity, meet the quantity, quality, and efficiency. 5) Orientation team,

According to Humairoh (2017: 3) basically all organizations have a distinctive organizational culture. Organizational culture is the basic pattern of shared assumptions, values, and beliefs that are considered as the correct way to think and act on opportunities issues facing the organization. An organizational culture defines what is important and not important in the company.

\section{Employee Engagement}

According Kreitner and Kinicki (2010) in Hasibuan (2019: 92), employee engagement is defined by the extent to which employees are motivated to contribute to organizational success, and are willing to apply the freedom to take independent decisions to complete the tasks critical to the achievement of organizational goals. According Schaufeli and Bakker (2004) in Akbar (2013: 13), the dimensions of employee engagement, namely: 1) Vigor (vigor), the level of high energy and mental toughness when it works, as well as a desire to give the business to work and resilience in the face difficulty. 2) Dedication (dedication), which is a significant feeling of jobs and caring for and interest in doing the work. 3) Absorption (appreciation),

According to Amanda (2017: 113) employee engagement as the empowerment of the members of the organization on their job roles, entanglement, people use and showed himself physically, cognitively and emotionally during play performance.

\section{Organizational Citizenship Behavior (OCB)}

According to Elmi (2019: 299) organizational citizenship behavior (OCB) used to describe the behavior of unknown individuals, express or implied by the formal reward system and overall (aggregate) support the effectiveness and efficiency of an organization. A person with a high organizational commitment will do more of the tasks that have become obligations voluntarily, dedication that are extra effort.

According Luthans (2011: 149-150), the dimensions of organizational citizenship behavior, namely: 1) Altruism, that behavior by individuals voluntarily in its role as an employee of a more altruistic rather than self-interest. 2) Civic virtue, namely behavior by individuals voluntarily in its role as an employee to participate and take responsibility in solving organizational problems for the survival of the organization. 3) Sportsmanship, that behavior by individuals voluntarily in its role as an employee in the form of tolerance to survive in a condition that is uncomfortable or unpleasant without complaining at all. 4) Conscientiousness, ie behavior by individuals voluntarily in its role as an employee to 
improve its performance in various ways, even when the need requires creativity and innovation in order to improve the organization. 5) Courtesy, that behavior by individuals voluntarily in its role as an employee to prevent problems in the organization because of the provocation from outside the organization as well as from individuals within the organization.

According to Amanda (2017: 113) organizational citizenship behavior mirror the actions performed by employees who go beyond the minimum requirement expected by the organization's role and promote the welfare of coworkers, work groups, and companies.

Framework

This study described the variables of leader member exchange (X1) and organizational culture (X2) that affect organizational citizenship behavior (Y2) through employee engagement (Y1) as mediation, then a framework can be described as follows:

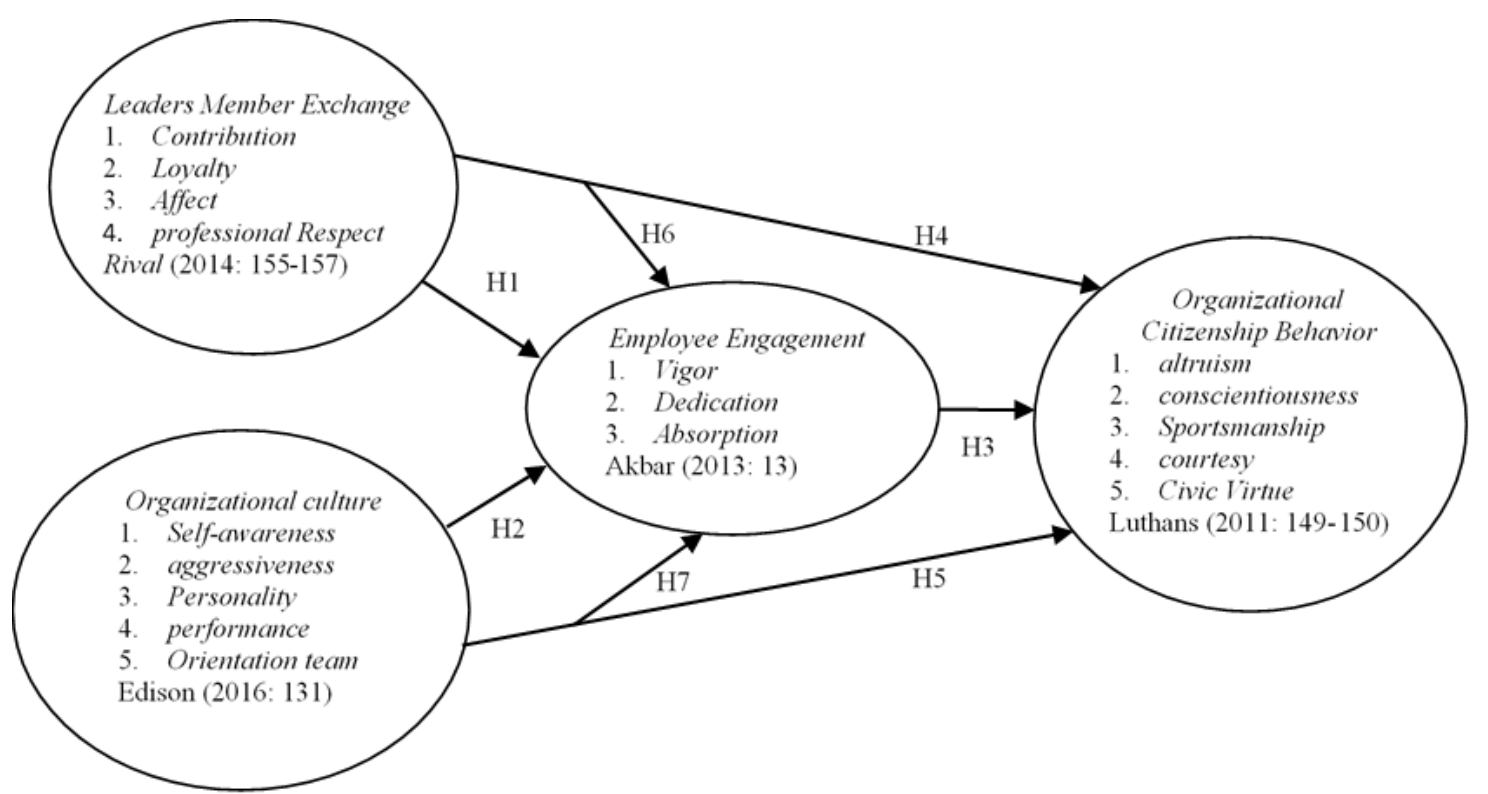

Picture 2. Fram ework

\section{RESEARCH METHODS}

Research design.

The method used is quantitative research with the verification method by collecting data through research instruments, and distributed questionnaires to employees whose results are then processed through a 6.0 WarpPLS program to determine the effect of variables that exist.

Research variable

Research using the independent variable is the leader member exchange (X1) and organizational culture (X2), mediating variables, namely employee engagement (Y1), and the dependent variable is organizational citizenship behavior (Y2). 
Population and Sample

The study population all employees of Perum LPPNPI many as 397 employees. The sample was measured with a Slovin formula, was found to be 200 as respondents.

Data collection technique

Primary data and secondary data

Data analysis technique

Processing data using WarpPLS 6.0, to find out and get a picture of the influence of the leader member exchange (X1) and organizational culture (X2) to organizational citizenship behavior (Y2) with employee engagement (Y1) as a mediating variable.

\section{FINDINGS AND DISCUSSION}

Based on the loading factor of each indicator in the variables and dimensions in this research worth over 0.7. Value loadings each of the indicators of a construct is higher than the value of the indicator cross loadings in other constructs. This proves that all the indicators are valid or have met the convergent validity.

Testing the validity of the second stage of testing discriminant validity. This test is based on measurement of the value of cross loading constructs and value Average Variance Extracted (AVE).

Table 1. Value Average Variance Extracted

\begin{tabular}{lc}
\hline \multicolumn{1}{c}{ variables } & Score AVE \\
\hline Leaders Member Exchange & 0.558 \\
Culture Organization & 0.570 \\
Employee Engagement & 0.543 \\
Organizational Citizenship Behavior & 0.583 \\
\hline Sources: Primary data are processed WarpPls 6.0 (2020)
\end{tabular}

Value Average Variance Extracted (AVE) for all study variables worth over 0.5 so that the value of AVE for testing discriminant validity has met and concluded that the research model was valid. Based on the PLS method, the reliability of the indicators in this study is determined by the value of Cronbach's alpha and composite reliability for each indicator.

Table 2. Values of Cronbach's Alpha and Composite Reliability

\begin{tabular}{lcc}
\hline \multicolumn{1}{c}{ variable } & $\begin{array}{c}\text { Cronbach's } \\
\text { Alpha }\end{array}$ & $\begin{array}{c}\text { composite } \\
\text { Reliability }\end{array}$ \\
\hline Leaders Member Exchange & 0.928 & 0.938 \\
Culture Organization & 0.946 & 0.952 \\
Employee Engagement & 0.895 & 0.914 \\
Organizational Citizenship Behavior & 0.949 & 0.954 \\
\hline
\end{tabular}

Sources: Primary data are processed WarpPls 6.0 (2020)

Each variable has had a composite value reliability above 0.7 and has had a Cronbach's alpha values above 0.6 so that it can be concluded have fulfilled the criteria of reliability and a measure that is trustworthy and reliable. 
Further testing structural models (inner model). This test is a test scale and the effect of latent variables independent of the dependent latent variables. This test Determinant coefficient $\mathrm{R}$ Square $\left(\mathrm{R}^{2}\right)$ is test that calculates how much the independent latent variables explain the variance of the dependent latent variables.

Table 3. Result R Squared (R2)

\begin{tabular}{lc}
\hline \multicolumn{1}{c}{ variable } & R2 \\
\hline Employee Engagement & 0.561 \\
Organizational Citizenship Behavior & 0.547 \\
\hline Sources: Primary data are processed WarpPls $6.0(2020)$
\end{tabular}

$\mathrm{R}^{2}$ value 0.561 means variable variable employee engagement employee engagement can be explained by the leader member exchange and organizational culture of $56.1 \%$ while the remaining $43.9 \%$ can be explained by other variable outside this research.

$\mathrm{R}^{2}$ value of 0.485 organizational citizenship behavior variable means variable organizational citizenship behavior can be explained by variables leader member exchange, organizational culture and employee engagement by $48.5 \%$ while the remaining $51.5 \%$ can be explained by other variable outside this research.

Hypothesis testing the structural relationships between variables using $6.0 \mathrm{WarpPls}$ can be seen from the path coefficient, and comparing the p-value $(\alpha)=0.05$. How decisions are:

- If the p-values $>0.05$, Ho is accepted and Ha rejected.

- If the p-values $<0.05$, Ho is rejected and Ha accepted.

Results of testing the hypothesis 1) the influence of the leader member exchange on employee engagement, 2) influence of organizational culture on employee engagement, and 3) the impact of employee engagement to organizational citizenship behavior using software WarpPls 6.0 can be seen in table 4 as follows:

Table 4. Estimation Results Direct Effect

\begin{tabular}{clccc}
\hline No & hypothesis & path Coefficients & P Value & Information \\
\hline & \multicolumn{1}{c}{ LMX $\rightarrow$ EE } & 0.46 & $<0.01$ & Significant \\
2 & BO $\rightarrow$ EE & 0.47 & $<0.01$ & Significant \\
3 & EE $\rightarrow$ OCB & 0.70 & $<0.01$ & Significant \\
\hline
\end{tabular}

Sources: Primary data are processed (2020)

The results of hypothesis testing can be seen in Table 4 can be explained each independent variable on the dependent variable as follows: The first hypothesis, based on the results of the analysis of the influence of the leader member exchange on employee engagement obtained $\mathrm{p}$ value of $<0.01$. $0.01 \mathrm{p}$ value $<0.05$ indicates that $\mathrm{H} 0$ rejected and $\mathrm{H} 1$ accepted. This result means that the leader member exchange positive and significant impact on employee engagement, which means the higher the leader member exchange given employer against an employee, the higher employee engagement employee,

The second hypothesis, based on the results of the analysis of the influence of organizational culture on employee engagement obtained $\mathrm{p}$ value of $<0.01 .0 .01 \mathrm{p}$ value $<0.05$ indicates that $\mathrm{H} 0$ rejected and accepted $\mathrm{H} 2$. This result means that the higher the organizational culture given employer against an employee, the higher employee engagementemployee, 
The third hypothesis, based on the results of the analysis of the effect of employee engagement to organizational citizenship behavior obtained $\mathrm{p}$ value of $<0.01 .0 .01 \mathrm{p}$ value $<0.05$ indicates that $\mathrm{H} 0$ rejected and accepted $\mathrm{H} 3$. This result means that the higher the superior employee engagement given to the employees, the higher the organizational citizenship behavior employee,

Results of testing the hypothesis 4) the influence of the leader member exchange on organizational citizenship behavior, and 5) the impact of organizational culture on organizational citizenship behavior using software WarpPls 6.0 can be seen Table 5 as follows:

Table 5. Estimation Results Direct Effect

\begin{tabular}{clccc}
\hline No & hypothesis & path Coefficients & P Value & Information \\
\hline 1 & LMX $\rightarrow$ OCB & 0.43 & $<0.01$ & Significant \\
2 & BO $\rightarrow$ OCB & 0.41 & $<0.01$ & Significant \\
\hline
\end{tabular}

Sources: Primary data are processed (2020)

The fourth hypothesis, based on the results of the analysis of the influence of the leader member exchange on organizational citizenship behavior obtained $\mathrm{p}$ value of $<0.01$. $0.01 \mathrm{p}$ value $<0.05$ indicates that $\mathrm{H} 0$ rejected and $\mathrm{H} 4$ accepted. This result means that the higher the leader member exchange given employer against an employee, the more organizational citizenship behavior employee,

The fifth hypothesis, based on the results of the analysis of the influence of organizational culture on organizational citizenship behavior obtained $p$ value of $<0.01 .0 .01$ $\mathrm{p}$ value $<0.05$ indicates that $\mathrm{H} 0$ rejected and $\mathrm{H} 5$ accepted. This result means that the higher the higher the organizational culture given employer against an employee, the more organizational citizenship behavior employee,

Results of testing the hypothesis 6) the effect of the leader member exchange on organizational citizenship behavior through employee engagement as a mediating variable and 7) influence of organizational culture on organizational citizenship behavior through employee engagement as a mediating variable using WarpPls 6.0 software can be seen in Table 6 as follows:

Table 6. Estimation Results Indirect Effect

\begin{tabular}{ccccc}
\hline No & hypothesis & path Coefficients & P Value & Information \\
\hline 1 & LMX $\rightarrow$ EE $\rightarrow$ OCB & 0.24 & $<0.001$ & Significant \\
2 & BO $\rightarrow$ EE $\rightarrow$ OCB & 0.21 & $<0.001$ & Significant \\
\hline
\end{tabular}

Sources: Primary data are processed (2020)

The sixth hypothesis, based on the results of the analysis of path coefficients or coefficient in the direct path between the leader member exchange effect on organizational citizenship behavior of 0.433 down to 0.239 on indirect effects and remain a significant pvalue, then the employee engagement partially mediate the effect of the organizational leader member exchange citizenship behavior, Thus, Ho is rejected and $\mathrm{Ha}$ accepted that employee engagement mediate part (partial mediation) the effect of exchange members of the organizational leader citizenship behavior, This result means that the higher the leader member exchange given by superior in Perum LPPNPI against subordinates, it will create a 
higher organizational level whether or not citizenship behavior created through employee engagement

The Seventh hypothesis, based on the results of the analysis of path coefficients or coefficient in the direct path between the effect of organizational culture on organizational citizenship behavior of 0.411 down to 0.214 on indirect effects and remain a significant pvalue, then the employee engagement partially mediates the influence of organizational culture on organizational citizenship behavior, Thus, Ho is rejected and Ha accepted that employee engagement mediate part (partial mediation) influence of organizational culture on organizational citizenship behavior, This result means that the higher the given organizational culture by superior in Perum LPPNPI against subordinates, it will create a higher level whether or not organizational citizenship behavior created through employee engagement.

\section{CONCLUSION AND SUGESTION}

1. Variable leader member exchange positive and significant direct effect on the variable employee engagement. This means that the member exchange quality of a good leader will make LPPNPI Perum employees in the group with the superior, otherwise the quality of superior and subordinate relationships are bad, then Perum LPPNPI or subordinate employee would be out goup.

2. Variable direct influence organizational culture positive and significant impact on employee engagement variables. Meaning Condition organizational culture that supports the work and development of Perum LPPNPI employees, as well as a friendly working conditions and mutual aid can also help in shaping the nature of the work engaged.

3. Variable employee engagement and significant positive direct effect on organizational citizenship behavior variables. That is the time Perum LPPNPI employee has engaged the company, they work with have an emotional attachment to the organization.

4. Variable leader member exchange positive and significant direct effect on the variable organizational citizenship behavior. This means that organizational citizenship behavior is the behavior beyond the call of duty where a behavior that is determined by the members of the organization, but nevertheless important for the viability and effectiveness of the organization.

5. Variable direct influence organizational culture positive and significant impact on organizational citizenship behavior variables. This means that organizational culture diterpakan by Perum LPPNPI employees who are required to create a stable environment, an employee of Perum LPPNPI that benefit on the job one of which adds to the experience.

6. Variable leader member exchange indirect effect positive and significant impact on organizational citizenship behavior variables in mediation by the variable employee engagement. This means that when an employee has LPPNPI Perum are emotionally attached to the company, the employee will work optimally to achieve the goals of the company. This means that with their employee engagement, it will strengthen the relationship between leader-member exchange on organizational citizenship behavior of employees of Perum LPPNPI. When employees feel appreciated by the company through leader-member exchange, the employee will feel emotionally attached to the company. When the feeling is tied, 
then the employee will provide positive behaviors such as organizational citizenship behavior to achieve the goals of the company.

7. Variable indirect influence organizational culture positive and significant impact on organizational citizenship behavior variables in mediation by the variable employee engagement. This means that when employees engaged in their work, they increase the occurrence of behaviors that promote the efficient and effective functioning of the organization. Their employee engagement and organizational culture can lead to a behavior of organizational citizenship behavior in employees in order to improve performance. Organizational culture as a pattern of basic assumptions that are found, created or developed by a certain group with the intention that the organization learns to overcome or cope with the problems arising from external adaptation and internal integration that has been running quite well

Suggestions can be given based on the analysis and discussion are as follows:

1. Suggestions for Perum LPPNPI

The result showed that there was a positive influence employee engagement to organizational citizenship behavior. Therefore, the company is expected to maintain a state organization that can improve employee engagement, such as providing the means to develop a career, support organizations, as well as their interaction with the employee leader. With increasing levels of employee engagement, then the employee readiness for change will also increase.

2. Suggestions for Further Research

Based on the research that has been stated previously, suggestions are given for further research is to conduct a more comprehensive study further by adding other variables in order to determine its effect on organizational citizenship behavior. Moreover, in order that the factors that affect organizational citizenship behavior can be studied in another company so that it can be concluded about the effect of other variables that affect organizational citizenship behavior in the company.

\section{REFERENCE}

Abbas, Muhammad. (2017). "The Effect of Organizational Culture and Leadership Style towards Employee Engagement and Their Impact towards Employee Loyalty". Asian Journal of Technology and Management Research (AJTMR), Volume 07- Issue 02, pp. 1-11.

Akbar, Muhammad Rizza. (2013). "Pengaruh Budaya Organisasi Terhadap Employee Engagement (Studi Pada Karyawan PT.Primatexco Indonesia Di Batang)". Journal of Social and Industrial Psychology, Vol. 2, No. 1, hal. 10-18.

Ali, Hassanudin dan Lilik Purwandi. (2017). Millenial Nusantara. Jakarta: Gramedia Pustaka Utama.

Amanda, Agustiani Rifania. (2017). "Pengaruh Employee Communication Terhadap Organizational

Citizenship Behavior Yang Dimediasi Oleh Employee Engagement Pada Karyawan Di Beberapa Fakultas Universitas Trisakti Jakarta”. Jurnal Manajemen dan Pemasaran Jasa, Vol. 7, No. 1, hal. 111-128.

Edison, Emron, Yohny Anwar dan Imas Komariah. (2016). Manajemen Sumber Daya Manusia. Bandung: Alfabeta.

Elmi, Farida. (2018). Telisik Manajemen Sumber Daya Manusia. Jakarta: Mitra Wacana Media. 
Elmi, Farida dan Widodo Murhanip0 (2019). "Organizational Citizenship Behavior Dalam Perspektif Islam Sebuah Studi (Aplikasi Taqwa) Terhadap Karyawan Industri Pendidikan”. MIX: Jurnal Ilmiah Manajemen, Volume 9, No. 2, hal. 298-311.

Hasibuan, Hasrul Azwar. (2019). "Dominasi Kepuasan Kerja Dalam Memoderasi Pengaruh Kepemimpinan Transformasional Terhadap Employee Engagement Pegawai ASN Di Medan”. Jurnal Kajian Ekonomi dan Kebijakan Publik, Vol. 4, No. 2, hal 90-98.

Humairoh. (2017). "Analisis Pengaruh Budaya Organisasi Terhadap Employee Engagement Dengan Kepuasan Kerja Sebagai Variabel Intervening (Studi Kasus: Perusahaan Jasa Layanan Pelabuhan)". Ultima Management, Vol. 9, No. 1, hal. 1-21.

Kartika, Dian. (2016). "Pengaruh Pertukaran Pemimpin-Anggota (LMX) Terhadap Kinerja Karyawan dengan Kepuasan Kerja dan Keterlibatan Karyawan Sebagai Variabel Mediasi (Studi Pada Hotel Bahari Inn Tegal)”. Diponegoro Journal of Management, Vol. 5, No. 2, hal. 1-14.

Northouse, Peter G. (2013). Kepemimpinan Teori dan Praktek. Jakarta: Indeks.

Rivai, Veithzal. (2014). Manajemen Sumber Daya Manusia untuk Perusahaan. Jakarta: Raja Grafindo Persada.

Suryadi. (2014). Sistem Pendukung Keputusan. Bandung: Remaja Rosdakarya.

Wibowo. (2013). Manajemen Kinerja. Jakarta: Raja Grafindo. 